\title{
Tōru Takemitsu's "Spherical Mirror:" The Influences of Shūzō Takiguchi and Fumio Hayasaka on his Early Music in Postwar Japan
}

\author{
Tomoko Deguchi*
}

\begin{abstract}
The music of Japanese composer Tōru Takemitsu (1930-1996) eludes understanding by traditional musical analytical approaches. In his earlier works, the musical language Takemitsu employed is influenced by Debussy, Webern, and particularly Messiaen; however, his music defies successful analyses by Western analytical methods, mainly to find an organizational force that unifies the composition as a whole. In this essay, I illuminate how his music was made to be "Japanesesounding," even though Takemitsu clearly resisted association with, and was averse to, Japanese traditional culture and quality when he was younger. I do this by examining Takemitsu's friendship with two individuals whom he met during his early age, who influenced Takemitsu at an internal level and helped form his most basic inner voice. The close friendship Takemitsu developed as a young composer with Shüzō Takiguchi (1903-1979), an avant-garde surrealist poet and also a mentor to many forward-looking artists, and Fumio Hayasaka (1914-1955), a fellow composer best known for his score to Akira Kurosawa's film Rashōmon, is little known outside Japan. In this essay, I discuss the following issues: 1) how Takiguchi's experimental ideas might have manifested themselves in Takemitsu's early compositions; and 2) how Hayasaka's mentorship, friendship, and ideals of the nature of Japanese concert music might have influenced Takemitsu's early pieces. I analyze some earlier compositions by Takemitsu to discuss the influences on his music by his two mentors, whose attitudes seemingly had come from opposite spectrums.
\end{abstract}

\section{Introduction}

The music of Japanese composer Tōru Takemitsu (1930-1996) eludes understanding by traditional musical analytical approaches. In his earlier works, the musical language Takemitsu employed is influenced by Debussy, Webern, and particularly Messiaen; however, his music defies successful analyses by Western analytical methods, mainly to find an organizational force that unifies the composition as a whole. I am a Japanese scholar, who was trained in the discipline of music theory in American institutions, and as a Japanese listener, I find Takemitsu's music to be "Japanese-sounding." In this essay, I illuminate on how his music sounds "Japanese," even though Takemitsu clearly resisted association with, and was averse to, Japanese traditional culture and quality when he was younger. ${ }^{1}$ I do this by examining Takemitsu's friendship with two

*Associate Professor of Music Theory, Winthrop University, USA.

1. Toru Takemitsu, Confronting Silence: Selected Writings, trans. and ed. Yoshiko Kakudo, and Glenn Glasow (Berkeley, California: Fallen Leaf Press, 1995), 142. Takemitsu wrote about his conflicting feelings towards Japanese traditional music, initially detesting 
individuals whom he met during his early age, who influenced Takemitsu at an internal level and helped form his most basic inner voice.

The close friendship Takemitsu developed as a young composer with Shūzō Takiguchi (1903-1979) and Fumio Hayasaka (1914-1955) is little known outside Japan. Takiguchi was an avant-garde surrealist poet and also a mentor to many forward-looking artists in various mediums and genres. Hayasaka, a fellow composer, was best known for his score to Akira Kurosawa's film Rashōmon, among many other film scores and concert music. ${ }^{2}$ At the time when Japan's identity and the sense of value were at a loss, ${ }^{3}$ Takemitsu sought out guidance from them for his career in music composition. In this essay, I discuss the following issues: 1) how Takiguchi's experimental ideas might have influenced Takemitsu's compositional career. Takemitsu's affection for Takiguchi is evident in the titles and inspiration for two of Takemitsu's early compositions which were taken directly from Takiguchi's poems. 2) How Hayasaka's mentorship and friendship during Takemitsu's formative years might have influenced Takemitsu's early compositions through Hayasaka's ideals of the nature and aesthetics of Japanese concert music. ${ }^{4}$ I will provide analyses of some portions of Distance de Fée for violin and piano (1951), the first movement of Pause Ininterrompue for solo piano (1952), and Requiem for Strings (1957), to discuss the influences on Takemitsu's music by Hayasaka, whose attitudes seemingly had come from the opposite spectrum of Takiguchi. In the title of this essay, "Spherical Mirror" is taken from the final line of Takiguchi's poem, but it comes to signify

any sound that reminds him of the old Japan. He considered himself as a composer who writes in modern Western style; however, he wrote, "I am not a composer who represents Japan, nor even a composer who is intentionally conscious of having Japanese nationality and incorporate Japanese elements into their music. But born and raised in Japan, even as I try to free myself from that influence, at the same time I became more aware that is impossible." He writes his early experience as a composer in his books such as Toi Yobigoe no Kanatani (Beyond the far calls) (Tokyo: Shinchosha Publishing, 1992).

2. Rashōmon was the first Japanese film that received good reviews internationally. It received the Golden Lion Award at the Venice International Film Festival in which Hayasaka's soundtrack was considered a contributing factor to the success of the film.

3. While Akira Miyoshi (b. 1933) was a guest lecturer in New York in 1993, he stated that, "because of the reversal of the sense of value simultaneous with the loss of war, because of the confusions that the adults showed, and because of the negation of the past and the loss of identity as a Japanese, us children in their teens felt a sense of nothingness." Quoted in Morihide Katayama, "Senzen, Senchuu, Sengo" (Pre-war, inter-war, post-war), in Nihon Sengo Ongakushi, Jōkan (Japanese history of concert music after World War II, Book 1), ed. Kōji Sano (Tokyo: Heibonsha Ltd., 2007), 51-52. My translation.

4. I define Japanese concert music as composed music by Japanese composers of which the stylistic features developed simulating the European classical music tradition. The Japanese music world discovered the European classical music after Japan ended national isolation in 1854. This term is used also in opposition to the Japanese traditional music and Japanese popular music. 
Takemitsu's metaphorical mirror, in which he portrays himself as gazing into both the Western and Japanese cultural aesthetics.

\section{Takemitsu and the End of World War II}

The year 1945 was significant for Japan, not only because this year marked the end of the World War II, but also because this year started the political, economical, and cultural transformation that happened in Japan in various facets and marked the beginning of the formation of the foundation of the modern day Japanese society. Takemitsu emerged as a young composer during this time of dramatic change. Needless to say, the world of Japanese concert music did not suddenly switch to a new phase in 1945; Japanese concert music continued to be created as a continuum of pre-war and inter-war creative energy. However, the ending of World War II was a significant factor to initiate the transforming movements in the postwar years that changed the stylistic idioms, mediums, techniques, and ideology, which still support and influence Japanese concert music. Today, Takemitsu is renowned internationally and is considered one of Japan's most successful composers who started their career in the midst of that time of transformation.

Takemitsu writes that he started his search for his own sound in the ruins after the fire of World War II. Perhaps somewhat fancifully, he recounts that as the war was approaching its end, he heard Lucienne Boyer singing the French chanson Parlez-moi d'amour from an old phonograph, and that it was the first time he became aware of the "beauty of music from Western culture." And it was this realization that brought about his desire to make a career of composing music in the Western style. ${ }^{5}$ Takemitsu was among the first generation, in fact, caught in the confrontation between Japanese values and radical westernization. Defeat forced young Japanese to be exposed and to absorb the culture of the West, primarily that of America. While working as a busboy at the occupation base, he was infatuated with the Western music that he experienced through radio broadcasts at the American military base. At the age of 15 or 16, he was determined to become a composer, not exactly knowing what it would take to become one.

The two early pieces under consideration, Distance de Fée and Pause Ininterrompue, both composed during his 20s, demonstrate the inception of Takemitsu's artistic individuality that came to fruition in later works. Both pieces were inspired by the two poems with the same titles by Takiguchi. Although the pitch derivation in these works utilizes Messiaen's pitch collections of limited transposition, notably the octatonic and nonatonic collections, the melodic writing

5. Takemitsu writes about his early musical experiences in Takemitsu, Toi Yobigoeno Kanatani, 27-28. 
in Distance de Fée exhibits an unmistakable Japanese quality, which consists of repetitions and embedding of patterns with similar contour. Hayasaka calls the resultant aural perception an "eternal form."6 The melodic writing in Distance de Fée is further developed in the Requiem for Strings, which made Takemitsu a household name in Japan. The evolution of the usage of the harmonic language in the earlier works reflects the forward-looking attitude that Takiguchi portrayed as an avant-garde artist. I will discuss these two individuals below.

\section{Musical Climate in Post-war Japan and Shūzō Takiguchi}

During the pre-war through the inter-war years, Japanese composers in general continued to absorb the compositional idioms that stem from the European classical music tradition, from the Classical and Romantic styles to the Neoclassical musical idiom, along with the French impressionistic style. The onehundred years of the Japanese compositional world since the country ended the national isolation was the epitome of the development of the Western concert music. It was after the war that the musical idioms developed by Boulez, Stockhausen, and Cage were introduced in Japan to the new generation of composers who were able to incorporate their styles only a few years after they were created. ${ }^{7}$ Especially Cage's idea of aleatoric music is credited for the removal of the wall between the meter-oriented musical time and the Japanese perception of non-metric musical time and the concept of ma. ${ }^{8}$ His aleatoric concept that divorces music from the meter and pulse freed the Japanese composers from the spell of European music. ${ }^{9}$ The Japanese composers of the postwar generation were no longer concerned with mere imitations of European music; instead they searched for their own voices in the midst of the sudden surge of diverse compositional approaches that poured in from the West. Takemitsu's generation initiated the development of their voices as composers of Japan.

In 1951, when Takemitsu composed his second completed work, Distance de Fée, he was 21 years old, and it was only six years since World War II had ended.

6. I have discussed this characteristic of the traditional Japanese melody elsewhere.

7. Kōji Sano, introduction to Nihon Sengo Ongakushi, Jōkan (Japanese history of concert music after World War II, Book 1), ed. Kōji Sano (Tokyo: Heibonsha Ltd., 2007), 15.

8. See Timothy Koozin, "Toru Takemitsu and the Unity of Opposites," College Music Symposium 30, no. 1 (1990): 34-44 for more discussion on Eastern ideals and Western techniques that are unified in Takemitsu's music.

9. Sano, introduction, 23-25. Cage's first visit to Japan was in 1962 as part of the avant-garde music concert series called Sōgetsu series. All the works of Takemitsu I discuss here were written before Cage's arrival in Japan, at which point Cage's concepts swept away the Japanese compositional scene. However, I believe that Takemitsu's early works have already shown that he was able to bridge the wall between European and Japanese concept of musical time. 
Unlike many of his contemporaries, who were fortunate to have been in environments in which they were exposed to Western classical music before the war (such as Akira Miyoshi, who is three years younger than Takemitsu, took piano and violin lessons when he was a child), Takemitsu was mostly exposed to Western classical music after the war ended. ${ }^{10}$ He studied music by endlessly listening to the American military's radio programs and by examining the scores of prominent composers' music at Civil Information and Educational Section library at the American General Headquarters. He has never studied composition formally at a music institution nor studied abroad.

Table 1. Groups that Were Formed Immediately after World War II

\begin{tabular}{|c|c|c|}
\hline 1946 & $\begin{array}{l}\text { Shinseikai新声会 } \\
\text { Group New Voice } \\
\text { "The Academics" }\end{array}$ & $\begin{array}{l}\text { Ikuma Dan, Yoshirō Irino, Namio Shibata, } \\
\text { Yūji Shigeta (all Saburō Moroi's students) } \\
\text { and other composers and performers. Since } \\
\text { 1949, the group became composers only. }\end{array}$ \\
\hline 1947 & $\begin{array}{l}\text { Shin Sakkyokuha Kyōkai } \\
\text { 新作曲派協会 New } \\
\text { Group of Composers } \\
\text { "The Nationalist" }\end{array}$ & $\begin{array}{l}\text { Yasuji Kiyose, Yoritsune Matsudaira, } \\
\text { Fumio Hayasaka, and } 6 \text { others. Later Tōru } \\
\text { Takemitsu and } 2 \text { others join. None of these } \\
\text { composers studied at a music institution. }\end{array}$ \\
\hline 1948 & $\begin{array}{l}\text { Chijinkai地人会 } \\
\text { "The Middleground" }\end{array}$ & $\begin{array}{l}\text { Kishio Hirao, Kōmei Abe, Saburō Takada, } \\
\text { and } 3 \text { others. }\end{array}$ \\
\hline 1951 & $\begin{array}{l}\text { Jikken Kōbō実験工房 } \\
\text { Experimental } \\
\text { Workshop }\end{array}$ & $\begin{array}{l}\text { Tōru Takemitsu, Hiroyoshi Suzuki, Jōji Yuasa } \\
\text { (all composition), Takahiro Sonoda (piano), } \\
\text { Kuniharu Akiyama (music critics, poetry), } \\
\text { Shōzō Kitadai (photography), Katsuhiro } \\
\text { Yamaguchi (sculpture), Hideko Fukushima } \\
\text { (painting), Naotsugu Imai (lighting), Hideo } \\
\text { Yamazaki (technician). Joined by } 5 \text { more } \\
\text { artists later. }\end{array}$ \\
\hline 1953 & $\begin{array}{l}\text { Sannin no Kai 三人の会 } \\
\text { Group of Three }\end{array}$ & $\begin{array}{l}\text { Yasushi Akutagawa, Toshirō Mayuzumi, } \\
\text { Ikuma Dan. }\end{array}$ \\
\hline 1953 & $\begin{array}{l}\text { Yagi no Kai 山羊の会 } \\
\text { Literally means Group } \\
\text { of Goats inspired by the } \\
\text { paintings by Picasso. } \\
\end{array}$ & $\begin{array}{l}\text { Hikaru Hayashi, Michio Mamiya, Yūzo } \\
\text { Toyama. Toshiya Sukegawa joins later. }\end{array}$ \\
\hline
\end{tabular}

Source: Nihon no Sakkyoku 20 Seiki (Japanese composers and compositions in the 20 th century) (Tokyo: Ongakunotomosha, 1999).

After the war has ended, like-minded composers formed groups for the purpose of promoting each other's works. Table 1 lists the representative groups

10. Kazuyuki Tōyama, Collection, Book 1 (Tokyo: Shinchosha Publishing, 1986), 265271. 
that were formed soon after the end of World War II, which contributed to the advancement of Japanese concert music. The first group formed was a group called Shinseikai (literally translates as Group New Voice). Founded in 1946, the group represented a new academism in postwar era made up of so-called "academic" composers. All were students of Saburō Moroi, who taught at one of the most prominent music institutions. In general, they followed the Western musical and technical idioms and their choices of compositional processes utilized Western formal archetypes by observing the importance of the organic developments of themes and motives. As a whole, they disliked the elements commonly associated with Japanese traditional music as compositional materials, since they believed they signified a cliché of Japanese folk music tradition. ${ }^{11}$ In particular, composers Namio Shibata and Yoshirō Irino showed interest in serial techniques. Later, together with Toshirō Mayuzumi and Makoto Moroi, they formed the Institution of the 20 $0^{\text {th }}$-Century Music and invited music critic Hidekazu Yoshida as the director of the Institution, who had just returned from Germany. ${ }^{12}$ They were considered as leaders of the compositional world who advanced the heritage of the Western classical tradition during post-war Japan.

In the opposite spectrum, group Shin Sakkyokuha Kyōkai (New Group of Composers), formed in 1947, seemed to advocate for Japanese nationalism. ${ }^{13}$ The members of the New Group of Composers included Yasuji Kiyose, who was Takemitsu's first and only private composition teacher. ${ }^{14}$ He invited Takemitsu to join the group where Takemitsu met Fumio Hayasaka for the first time, which led to a lifelong friendship. Takemitsu joined this group only to withdraw later and

11. Nihon no Sakkyoku 20 Seiki, 39.

12. Tōyama, Collection, Book 1, 269.

13. Here, the influence of Russian composer Alexander Tcherepnin, who advocated for Japanese nationalism, cannot be overlooked. Six of the founding members of the New Group of Composers were recognized by Tcherepnin and their music was published in Paris, Vienna, and New York through Tcherepnin edition. Alexander Tcherepnin was the son of composer Nikolai Tcherepnin who sought asylum in France at the outbreak of the Russian Revolution. Alexander's visit to China led him to reside in Shanghai for a few years. While in Shanghai, he developed a strong interest in Japan and Japanese composers that resulted in providing opportunities to many of them. Tcherepnin wrote a message to Japanese composers in a music journal Ongaku Shinchou (August, 1936) stating, "be faithful to your own culture. Express your own cultural life in music. You will build a true Japanese nationalistic music when you take inspiration from folklore, consider traditional culture as a strong foundation, and preserve folk tunes and Japanese traditional music and develop them in a multitude of ways. When your music is truly nationalistic, its international value should increase." My translation.

14. It is known that Takemitsu's lessons with Kiyose did not entail teaching of actual compositional techniques. They mostly spent time discussing the issues and topics of art in general. See Jun Kobayashi, Nihoneigaongaku no Kyoseitachi I (Bright stars in the Japanese film music I) (Tokyo: Waizu Shuppan, 2001), 142. 
became one of the founding members of a more radical group called Jikken Kōbo, or Experimental Workshop. Experimental Workshop comprised of composers, performers, and artists from other genres, and formed under the guidance of Shūzō Takiguchi, who also named the group.

Takemitsu left the New Group of Composers because the group's inclination to nationalism did not bode well with Takemitsu's more forward-looking perspectives. ${ }^{15}$ Perhaps it was not satisfactory for Takemitsu that the works presented at the concerts were mostly based on the existing idioms of Western form (mainly Neoclassicism) combined with Japanese elements such as the pentatonic folk-like melodies. ${ }^{16}$ He likely resisted any vestige of the wartime compositions that combined Japanese tunes with orchestral harmonization by means of Western tonal syntax, with titles drawn from Japanese images, sceneries, or locations. The purpose of the nationalistic music during wartime was to enhance national prestige, thus works with references to Japanese traditional arts, texts, folk tunes, and locations enumerated the Japanese concert scene. ${ }^{17}$ Takemitsu later recalled his feelings towards the New Group of Composers:

When I joined the New Group of Composers, I came to realize that the principle I have to fight is the Japanese nationalism. My music started by denying the direction that the nationalism was taking. ...I experienced physical repulsion towards the sounds from Japanese vernacular, and had a strong feeling, without any reason, that we need to reject music similar to the politically charged wartime compositions. ${ }^{18}$

Later Hayasaka also left the New Group of Composers, but he continued to promote the notion of pan-Asianism, culminating in his famous interview that was published in the popular music journal Ongakugeijutsu in 1954. ${ }^{19}$ Considering the close friendship and admiration Takemitsu had for Hayasaka, there is no doubt that Takemitsu was influenced by his way of thinking.

15. Takashi Tachibana, "Takemitsu Tōru: Ongaku Souzoueno Tabi daisankai" (Tōru Takemitsu: Journey to music creation no. 3), Bungakukai (1992), 274.

16. Tōyama, Collection, Book 1, 269. Although Takemitsu's first composition that was performed publicly titled Lento in Due Movimenti used pentatonic inspired melodies.

17. Some examples of the Japanese compositions that were on radio broadcast during wartime include: The Land of the Rising Sun, Prelude of the Early Spring and March by Yamada, Looking up at Chiyoda Castle by Eguchi, Kimigayo (Japanese anthem) March by Yoshimoto, Ode to the East-Asia by Takada, and numerous others.

18. Takemitsu, Takemitsu Tōru Taidanshuugekan: Sōzō no Shūhen (Tōru Takemitsu's collection of dialogue vol. 2: Around creation) (Tokyo: Geijutsugendaisha, 1976), 145-146. My translation.

19. Atsushi Miura, and Fumio Hayasaka, "Hayasaka Fumio to Han-Tōyōshugi Ongakuron" (Fumio Hayasaka and musical discussion on pan-Asianism), Ongakugeijutsu (August, 1954): 8-20. 
Hayasaka died young in 1955 at the age of 41 years old, but his vision was passed on to Takemitsu. ${ }^{20}$

Takemitsu continues from the above quote, "As a reaction (to the repulsion towards the sounds from Japanese vernacular), I jumped to the music that was imported fresh from Europe and America."21 Takemitsu was one of the founding members of Jikken Kōbo or Experimental Workshop that was founded in 1951, a year before he left the New Group of Composers.

Experimental Workshop consisted of musicians, artists, and novelists, who promoted new and experimental directions in the arts, and Shūzō Takiguchi became the spiritual leader of this group. ${ }^{22}$ Experimental Workshop was a congregation of artists who were truly the postwar generation; all of them were in the early 20s and none of them had any established place in the prewar and interwar periods. ${ }^{23}$ The group was decidedly anti-academic biased, and in fact any kind of formal training was a barrier to its membership. ${ }^{24}$ At that time, Takiguchi, twenty-seven years senior to Takemitsu, was already established as an avant-garde surrealist poet and visual artist since the 1930s. He is also famous for the décalcomanie production and his writings on art criticism as well. The formative years of the members of the Experimental Workshop coincided with the period in which Takiguchi's writings began to appear in art magazines and newspapers with increasing frequency. ${ }^{25}$

Takiguchi's poems Pause Ininterrompue and Distance de Fée published in 1937, from which Takemitsu borrowed the titles for his compositions, foreshadowed the dark age of military domination. ${ }^{26}$ These two poems were included in Takiguchi's poetry book with illustrations also titled Distance de Fée. Around this time, the militarization in Japan proceeded at a fast pace. During the entire fifteen years in 1931-1945, Japan was involved in war to some extent. In 1941, Takiguchi was imprisoned for eight months for creating surrealistic poems and arts, which were deemed corrupted as they were being influenced by the West, thus his

20. Takemitsu composed the Requiem for Strings grieving for Hayasaka's death as well as his own fear of death by tuberculosis, as I will discuss below.

21. Takemitsu, Takemitsu Tōru Taidanshuugekan. My translation.

22. Miwako Tezuka examines Jikken Kōbō in relation to Japan's postwar rebuilding through its socio-historical context. See her dissertation Miwako Tezuka, Jikken Kōbō (Experimental Workshop): Avant-Garde Experiments in Japanese Art of the 1950s (PhD dissertation, Columbia University, 2005).

23. Ibid., 19.

24. Peter Burt, The Music of Toru Takemitsu (Cambridge: Cambridge University Press, 2001), 39.

25. Tezuka, Jikken Kōbō, 26.

26. Shin Ōoka, Mikurokosumosu Takiguchi Shūzō (Microcosmos, Shūzō Takiguchi) (Tokyo: Misuzushobō, 1984), 33. The inter-war Japan was permeated by the aggressive militarism that hauled the nation to the eventual defeat and the totalitarianism that oppressed the individuals. See Katayama, "Senzen, Senchuu, Sengo", 47. 
works considered unpatriotic by the Japanese government. Two factors worsened his reception in Japan in comparison to the works that expressed Japanese-style lyricism that boded well with the fascist government: 1) the fact that Takiguchi was always monitored by the military authorities after his release; and 2) his writing style is more personal with psychological expressions. ${ }^{27}$ The poem Pause Ininterrompue, in particular, reflects the strained feelings of oppression. Here is a translation of this poem: ${ }^{28}$

The endless fluttering of the wings

Of the young moth tolerates the weight of the massive bottle

The transient white bust freezes in the memories of snow

The stars perch on the thin branch and adapt to the meager illumination

Everything

Motionless spherical mirror on top of the hill

With the second line, "Of the young moth tolerates the weight of the massive bottle," the poem expresses the oppressive atmosphere of the Japanese society. The line, "The stars perch on the thin branch and adapt to the meager illumination" illustrates the dim hopelessness of the time. The word "motionless" from the final line might evoke an image of death. Even the title Pause Ininterrompue might suggest death by implying the image of "uninterrupted sleep from never waking up." Takemitsu, who suffered from poor health when he was young, might have been anticipating death himself. Tsuruoka interprets the last sentence that the "mirror" reflects the expecting of the even harsher future. ${ }^{29}$

Takemitsu, though unconsciously, sympathized with this feeling of pressure reflected on his own situation, hence borrowing the titles of Takiguchi's poems Distance de Fée and Pause Ininterrompue for his own compositions. Compared to Takemitsu's predecessors and privileged contemporaries who were exposed to Western music since their youth and have been educated at various music institutions and many of them even studied abroad, Takemitsu did not have the similar opportunities towards his study in composition and it is easy to imagine that he might have felt a sense of inferiority. It is well known that his first publicly presented piece received a harsh criticism as "pre-music." ${ }^{30} \mathrm{He}$ must have felt

27. Yoshihisa Tsuruoka, "Kyouhakusareta Zettaizetsumei: 'Yousei no Kyori' kara 'Te' e" (The threatened serious crisis: from Distance of Fairy to Hand), Hon no Techou (August 1969): 430.

28. My translation.

29. Tsuruoka, "Kyouhakusareta Zettaizetsumei", 435.

30. Kuniharu Akiyama, Nihon no Sakkyokukatachi: Sengokara Shin no Sengotekina Mirai e (Japanese composers: from post-war to truly post-war like future) (Tokyo, 1979), 356. It is well known that the music critic Ginji Yamane wrote in the Tokyo Newspaper that Takemitsu's maiden work Lento in Due Movimenti, written in 1950, is "pre-music," meaning that the work sounded as if written by an amateur. Köji Sano writes that he had 
isolated from some of his contemporaries such as the academics who studied at top-notch institutions under established composers, who utilized the Germanstyle serialism, French impressionistic style, and/or Neoclassicism. For instance, the members of the Group of Three were already gaining national attention, who had been enthusiastically promoting and also had the means to fund their large orchestral works. ${ }^{31}$ The Experimental Workshop gave Takemitsu an opportunity to belong and to work with like-minded artists, at the time he felt as an outsider to the highly conservative world of the institutional Japanese academic establishment. ${ }^{32}$

Experimentation was Takiguchi's conviction. His belief in experimentation was expressed by titling one of his collections of poems Poetic Experiment. In the new age of the postwar, armed with the fresh view of the world and developments in the new media and technology, Takiguchi believed that the time had come to attempt new experiments that combined different genres. Experimental Workshop included not only musicians but also visual artists and stage technicians who had strong determination to start something "new." "Experiment" is the spirit that Takemitsu inherited from Takiguchi. ${ }^{33}$ Takiguchi encouraged the members to consider the importance of the act and creation of the art work itself, rather than the perfection of the end result. Japanese artists had always been obsessed with the stylistic newness of imported "-isms" from the

asked the late composer Namio Shibata (1916-1996) about this remark by Yamane. Shibata replied, "Yes, we agreed. We did not think the Two Lentos as music." Sano asked the same question to Makoto Moroi (b. 1930) and he replied, "We did not think they were written by professionals. However, there were aspects that were very agreeable." See Sano, introduction, 31. Distance de Fée was written soon after Lento.

31. By the early 1950s, the three members of Group of Three, Ikuma Dan, Yasushi Akutagawa, and Toshirō Mayuzumi, were already enjoying the status as young and promising composers. They have seen great success in providing music to mass media such as films and journalism. The purpose of this group was to compose and fund the performance of their compositions that will speak to the society apart from commercialism and overt academism, which they believed did not connect with the general public. See Satoru Takaku, "Sengosedai no Taitou" (The rise of the post-war generation), in Nihon Sengo Ongakushi, Jōkan (Japanese history of concert music after World War II, Book 1), ed. Kōji Sano (Tokyo: Heibonsha Ltd., 2007), 207.

32. Burt, The Music of Toru Takemitsu, 39.

33. Even after the Experimental Workshop ceased its activities and the group dissolved, Takemitsu continued his quest to experiment with different genres, styles, and medias. The music he composed in his career included chance music, tape music, music concrete, and works with Japanese traditional instruments, and all were part of his experiments. Soundtracks for films were also a perfect medium to experiment with sound effects. Believing in his instinctive choice of sounds, he used these compositional resources to create and experiment in order to further search for his own sound. Eventually he returned to the more traditional settings of instruments and used less technology and fewer traditional instruments. 
West and had been easily allured into their imitation, and Takiguchi encouraged to overcoming that. ${ }^{34}$ Following Takiguchi's guidance, the members felt free to create within their own sensitivity rather than to pursue specific methods, trends, or idioms. Takiguchi entrusted to them the task of reviving and continuing the avant-garde movement that once flourished around him but was halted during the war. ${ }^{35}$

\section{Fumio Hayasaka's Belief on Japanese Sensibility}

The reaction for Takemitsu was to go against the nationalistic movement when the war ended. ${ }^{36}$ His bitter experiences during the war, and his admiration of Western culture led to what Takemitsu described as "gazing only into the mirror of Western music and Western art."37 However, at the same time, traces of subtle but unmistakable Japanese qualities can be seen in Takemitsu's music, even in the early pieces in which Takemitsu's compositional style was modeled after the Western composers. Although Hayasaka had never provided composition lessons for Takemitsu, it is said that Takemitsu learned orchestration hands-on while Takemitsu assisted Hayasaka with the sound tracks for films. Hayasaka would teach Takemitsu about Japanese traditional performing arts such as Gagaku and $N \bar{o}$, and in return Takemitsu would tell Hayasaka about newly encountered music such as Messiaen's compositions. Takemitsu became deeply influenced by Hayasaka's notion of pan-Asianism.

34. Tezuka, Jikken Kōbō, 28.

35. Ibid., 29.

36. For a discussion on the neonationalist movement in postwar Japan, see Judith Ann Herd, "The Neonationalist Movement: Origins of Japanese Contemporary Music," Perspectives of New Music 27, no. 2 (1989): 118-163. Unlike Takemitsu, the members of Yagi no Kai (Group of Goats) actively pursued the wealth of resources in Japanese traditional music. Their model was Béla Bartók who, according to one of the members Hikaru Hayashi, "composed music that avant-garde and realism co-existed, and whose perspective originated from both international and ethnicity based on strong technical foundation" (Sano, Nihon Sengo Ongakushi, Jōkan, 210). Following the historical development of nationalism, it was natural for the members to adapt collected folksongs and dances to utilize in the thematic materials, structural models, and inspiration, which they called neonationalist movement (Herd, "The Neonationalist Movement", 132). The members of Sannin no Kai (Group of Three) also brought back the idea of deeply rooted Japanese-ness incorporating Japanese literary themes, unusual blends of timbre and texture, and the principle of asymmetry in Japanese arts as limitless potential sources (Herd, "The Neonationalist Movement", 138).

37. Takemitsu, "Contemporary Music in Japan," Perspectives of New Music 27, no. 2 (1989): 201. 
In June 1954, a music journalist Atsushi Miura visited Hayasaka and interviewed him for two and a half hours. ${ }^{38}$ The interview appeared in the journal Ongakugeijutsu. Here, Hayasaka summarizes his belief to instantiate the Japanese qualities into compositions. By Japanese quality, he did not refer to the pre- and inter-war techniques of referring to Japanese arts, locations, or tunes in the compositions, but to search for the simple, primitive beauty, on which the Japanese culture was founded and developed. The following is among Hayasaka's ideas:

\begin{abstract}
"My wish is to come up with a new form of music that can compete with music from the Western tradition. As a Japanese composer, I want to write music that has a combined quality of $20^{\text {th }}$-century musical style and Japanese sensibility. For me, Japanese quality means simplicity, endlessness, irrationality, two-dimensional, and plant-like. These qualities can be contrasted to the Western qualities of complexity, conclusiveness, rationality, architectural, and with human emotions... For instance, we don't have concepts such as dialectic development as seen in Sonata form. Our way of thinking is that rather than taking interest in the correlation of two or more things, there is only one thing to focus on. To express this aesthetic, we can refer to Noh Theater or picture scrolls. It is ultimately a form of "no-form." The Western architecture builds up by piling structure up, but the Japanese architecture consists of combining two planes. We have to adapt and reflect this kind of aesthetics to harmonic and rhythmic construction, combining of voices, melodic formation, and the overall pacing of the music." ${ }^{39}$
\end{abstract}

For the three Japanese qualities Hayasaka mentioned above, irrationality is the opposite of rationality as represented by serial technique, which he criticized it as an epitome of the rational German music constructed by theoretical functionality that Japanese composers should avoid. By the quality of twodimensional, he contrasted the differences in Western and Japanese architectural style in that Japanese traditional architecture is built by combining two individual planes. This is to emphasize the importance of the parts rather than the whole, as the whole is the result of combining the parts. It relates to the form of music in which Hayasaka points to the similarity to the picture scroll. He advocates for the music whose form is an amalgamation of related parts that are independent by themselves..$^{40}$ By the quality of plant-like, I believe he meant that the music should not be aggressive or overtly emotional.

38. Yūichirō Nishimura, "Kurosawa Akira to Hayasaka Fumio: Kaze no youni Samurai wa" (Akira Kurosawa and Fumio Hayasaka: Samurai like the wind) (Tokyo: Chikumashobō, 2005), 745-746.

39. Miura, and Hayasaka, "Hayasaka Fumio to Han-Tōyōshugi Ongakuron, 13.

40. Hitomi Sano, "Takemitsu Tōru to Senzen no 'Minzokuha' Sakkyokukatachi: Kiyose Yasuji, Hayasaka Fumio to 'Nihon tekina mono' no Ninshikinitsuite" (Toru Takemitsu and 'Ethnic' Composers of the Prewar Period in Japan: Yasuji Kiyose, Fumio 
In the same interview, Hayasaka talked about rhythm that "it is appealing when the music adopts the Japanese sense of rhythm that is not immediately notable. The fascination is in the complexity of combining the strict and freer rhythm as seen in Nō Theatre."41 Hayasaka advocated for atonality in that "it is not possible to express the Eastern sensibility with tonality. But the Japanese composers' use of atonality has to accommodate the Eastern sense and cannot be systematic."42

It was not Hayasaka's intention to compose music that "sounds like Japanese," nor is he against music that follows intellect or logic. He has never devised any concrete compositional methods or systems that reflect his ideas of the Japanese quality. As a composer with a vast knowledge of Japanese traditional cultures such as visual art, architecture, and literature, Hayasaka believed that Japanese composers must cultivate Japanese sensibilities through other Japanese arts in order to achieve that goal. Many Japanese composers were influenced by this attitude. Hayasaka also states, "if the Western culture is a culture of existence, the Eastern culture is a culture of nothingness. My ultimate goal is to express this nothingness." 43 This concept is not new according to the philosophers of the Kyoto School (especially Masaaki Kōsaka), who had greatly influenced the young intelligentsia during the inter-war. According to Kōsaka, there were no concepts as "eternal existence of the only god," or "human absolutism." If there is no "absolute existence," then there is only "nothingness" that the universe started from. This is what Hayasaka and the others claimed that they should follow as Japanese composers. ${ }^{44}$ Even though Takemitsu detested Japanese nationalism as something related to the war and the old constitution of pre- and inter-war Japan, Hayasaka's desire to retain Japanese sensibilities in postwar concert music is reflected in Takemitsu's compositions.

Takemitsu's strong fondness of Messiaen is evidenced in his compositions Distance de Fée and Pause Ininterrompue, as they incorporate Messiaen's modes of limited transposition, especially the octatonic collections. Below, first I will discuss the harmonic construct of these works in order to show Takemitsu's experimental spirit at the early stage of his career by trying out new compositional materials influenced by Messiaen's harmonic construct. However, some obscurities of pitch derivation contribute to the sense of obscure boundaries that reflect Hayasaka's ideal of the Japanese sensibility. Then, in contrast to the harmonic construct that originated in Western techniques, I will show

Hayasaka, and their Recognition of 'Japanese' Music), Hyougenbunkakenkyū 10, no. 2 (March 2011): 178.

41. Ibid.

42. Ibid.

43. Miura, and Hayasaka, "Hayasaka Fumio to Han-Tōyōshugi Ongakuron".

44. Katayama, "Senzen, Senchuu, Sengo", 50. 
Takemitsu's melodic writing in Distance de Fée, which reveals Japanese sensibilities that continues to be exhibited in the melodic writing in Requiem.

\section{Takemitsu's Early Music}

Figure 1 shows the first three measures and a half in Distance de Fée. In the piano accompaniment, the chords in $\mathrm{mm}$. 1-3 are all comprised of octatonic collection I, ${ }^{45}$ except for the circled pitch A in mm. 1-2 and pitch Eb that doubles the violin in $\mathrm{m}$. 3. Takemitsu utilizes the property of the octatonic collection from which he constructs the familiar tertian chords. Pitch A acts as a foreign object foretelling the later emergence of collections II and III. Collection II is utilized explicitly in the violin melody starting with the anacrusis pitch to $\mathrm{m}$. 3 to the first half of m. 4 , and collection III is utilized explicitly in the violin melody starting from the second half of m. 4 to m. 6 (Figure 2). The first two pitches in the violin melody, pitch-classes 5 and 8, are common tones between the two collections I and II, thus blurring the boundary of the regions of the two collections. The piano accompaniment's melodic segment, E-F-G-Ab as top notes in $\mathrm{m} .1$ are restated combining the piano and violin melodies in $\mathrm{mm}$. 2-3. Also, the first 5-note chord in the piano in $\mathrm{m} .4$ shows ambiguity in that it includes three invariances between collections I and II, thus obscuring the pitch resources.

Figure 2 shows the second half of m. 4 to m. 6 of Distance de Fée. Similar to the first measure, the traditional tertian chords in the second half of $\mathrm{m} .4$ are derived from collection I, except for pitch-class 9, this time foreshadowing collection III. In the beginning of the violin melody in figure 2, Takemitsu alternates the pitches that are derived from collections III and II (pitch-classes 9 and 0 are common-tones between collections II and III), again obscuring the boundary of the two collections. In m. 5, Takemitsu uses pitch resources other than the octatonic collections. The first chord in m. 5 is a subset of Messiaen's mode 3 (that I call the nonatonic collection, which is a complementary set of the augmented triad). Subsets of Messiaen's mode 3 are utilized even more in Takemitsu's Requiem. The second large chord in $\mathrm{m} .5$ is a member of set-class 7-33 [012468T], which is a whole-tone collection plus one pitch. Takemitsu utilizes this chord in many of his compositions, which Peter Burt identifies as Takemitsu's signature chord among the composer's harmonic vocabulary. ${ }^{46}$ The other pitches in $\mathrm{m} .5$ and all pitches in $\mathrm{m} .6$ derive from collection III, where the melodic motion signals the end of the first section of this piece. This

45. I adopted the numberings of the collections from Peter van den Toorn's book on Stravinsky's Rite of Springs. Oct I: $\{1,2,4,5,7,8, T$, E $\}$, Oct. II: $\{0,2,3,5,6,8,9$, E\}, Oct. III: $\{0$, $1,3,4,6,7,9, T$.

46. Burt, The Music of Toru Takemitsu, 34. Burt shows Takemitsu's usage of this chord in the composer's other works throughout his book. 
sectional ending is signified by the unification of the pitch derivation utilizing collection III in both the melodic and the harmonic construction. The same method is also used in the Requiem.

Figure 1. Distance de Fée, mm. 1-4

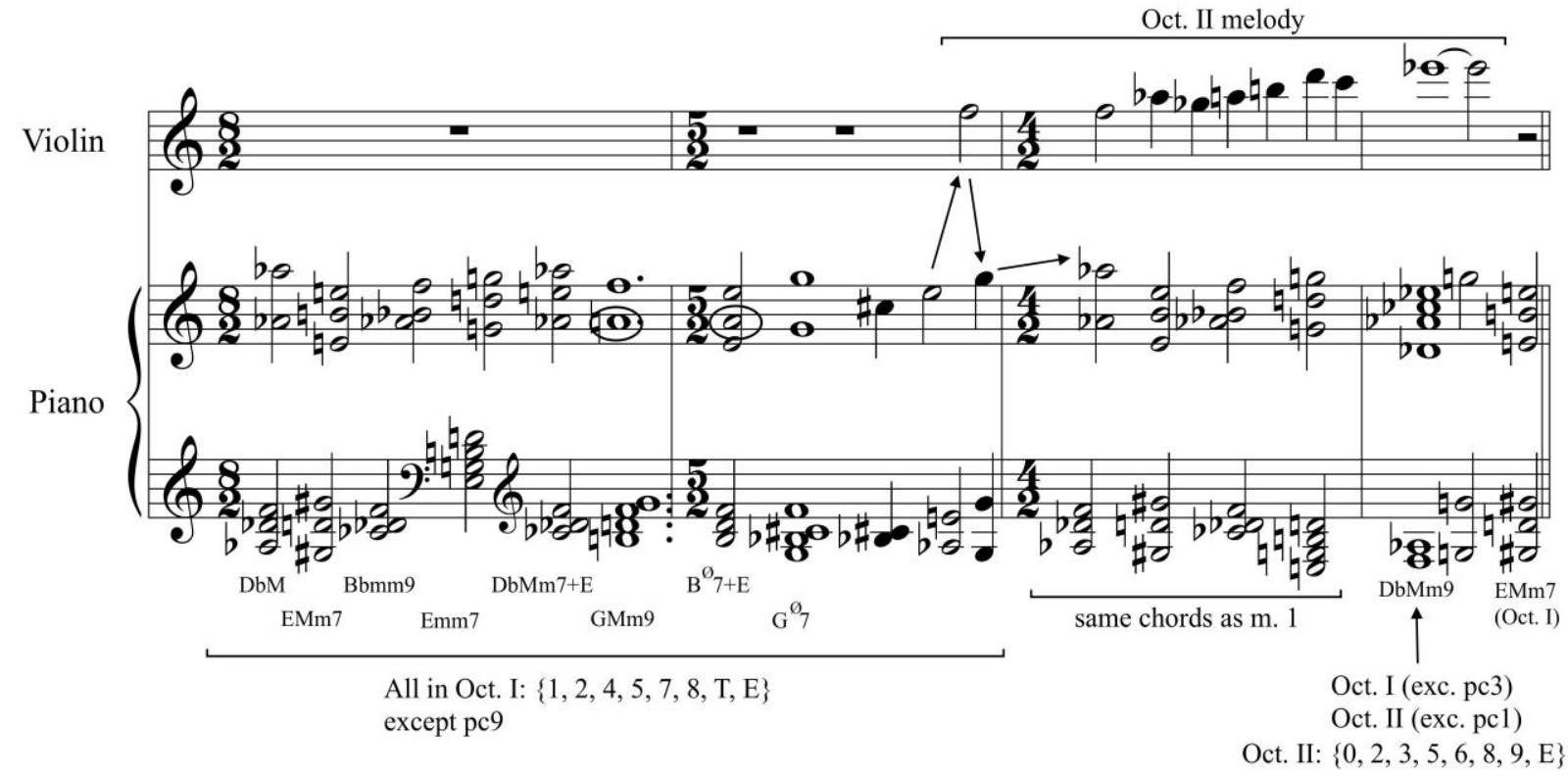

Source: Distance de Fée, 1951.

Figure 2. Distance de Fée, mm. 4-6

Violin
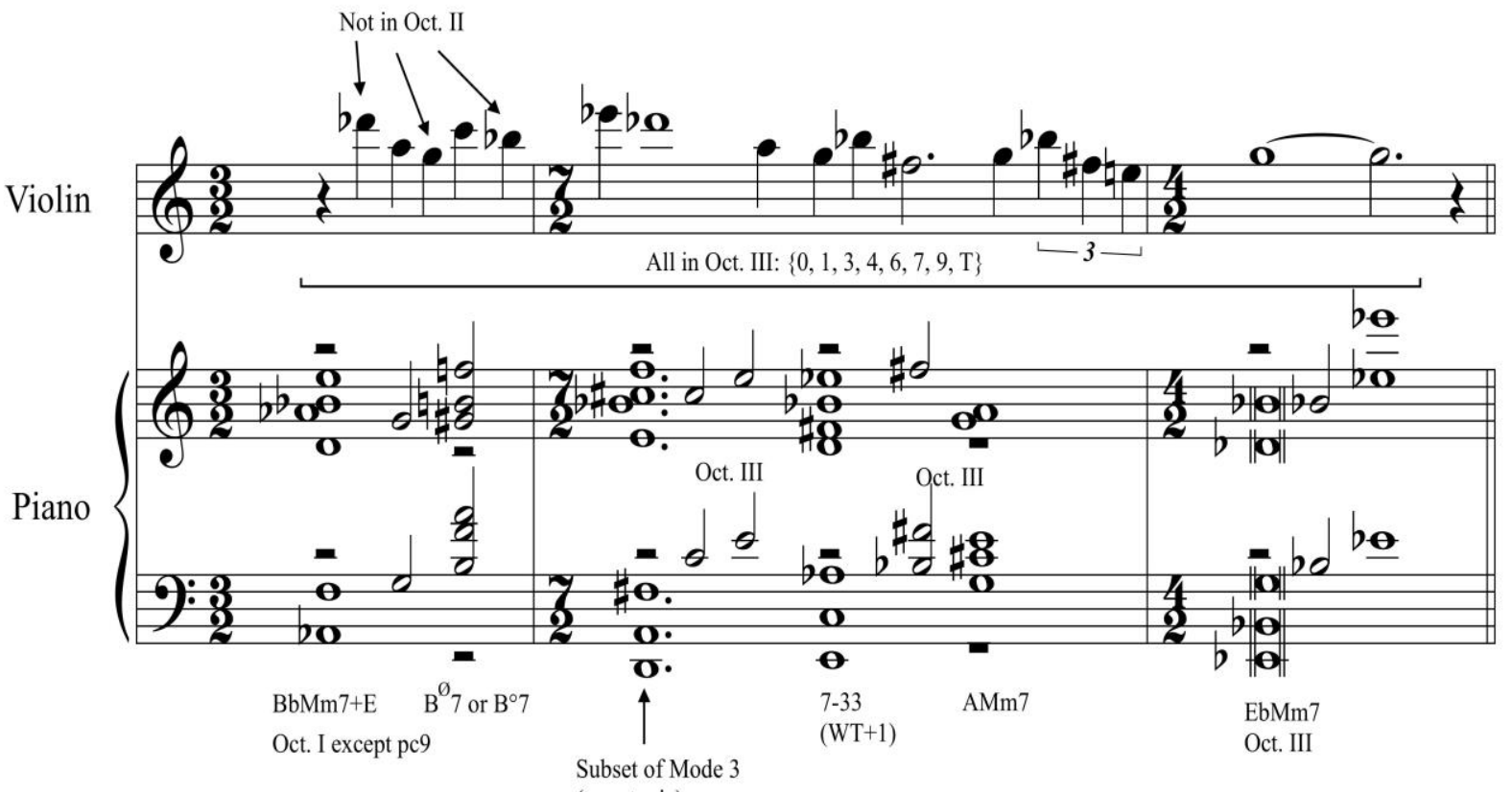

Source: Distance de Fée, 1951. 
Figure 3 shows the first two measures of the first movement of Pause Ininterrompue. Takemitsu no longer uses a time signature with this piece. The score for Pause Ininterrompue is one of the first instances of the usage of extended beams and undefined pitch duration, however, here, I incorporated the usual note durations for clarity. In this example, the three octatonic collections are presented successively, and at times simultaneously. Smooth connections are achieved by a pitch in the extreme register (most of the time), which acts as a common tone to move away from one collection to another. In the beginning, pitch $\mathrm{Cb} 4$ belongs to both collections I and II, D5 belongs to collections I and III, and A3 belongs to collections II and III. Both in Distance de Fée and Pause Ininterrompue, the pitch resources are obscured by means of invariances and by superimposition of two different octatonic collections, sustaining the coexistence of different planes.

Figure 3. Pause Ininterrompue, I, mm. 1-2

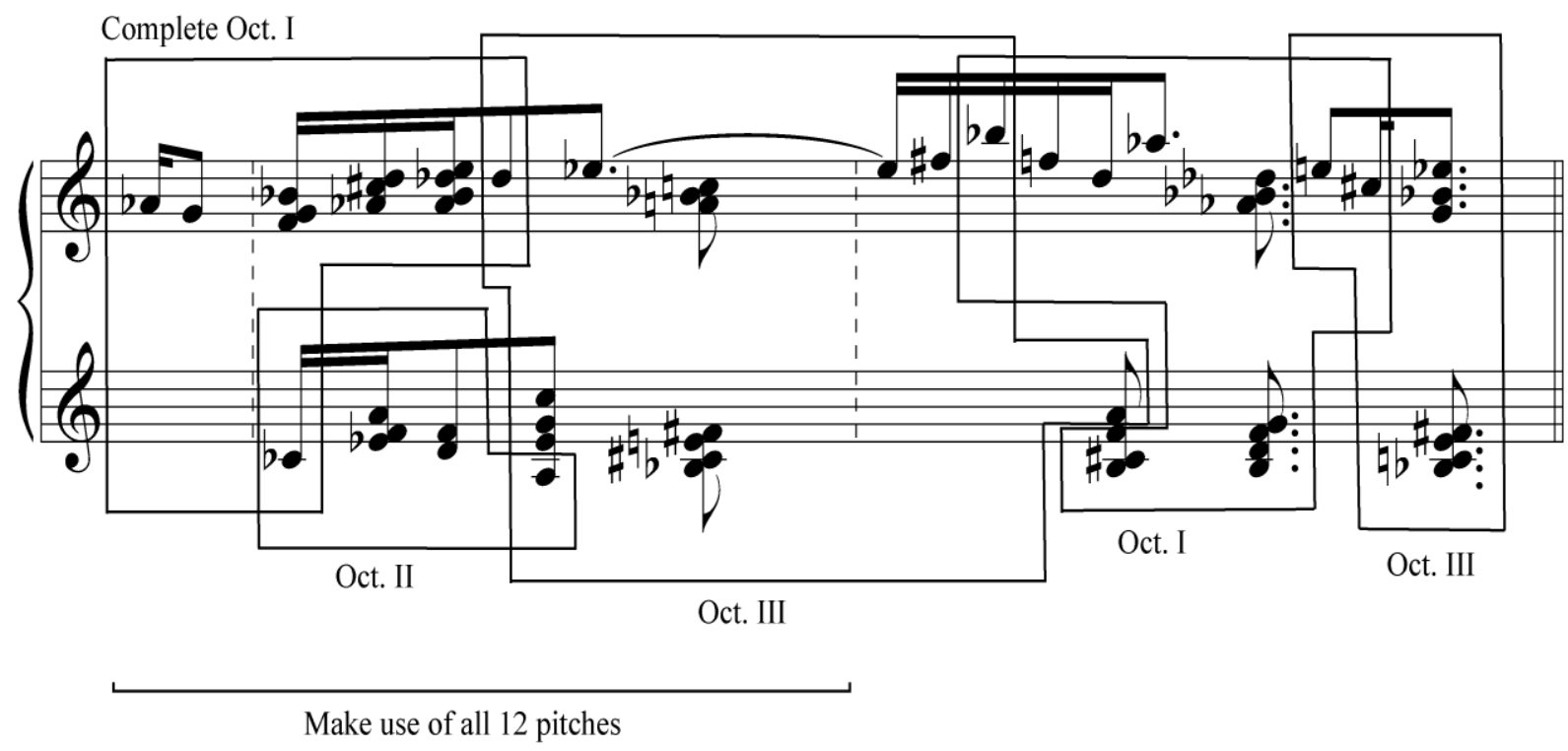

Source: Pause Ininterrompue, 1952.

Contrasting with Takemitsu's desire to utilize the Western techniques of pitch structure, his melodic construction of Distance de Fée is influenced by Hayasaka's notions of Japanese qualities. Figure 4 shows that the melodic line consists of embedded three-note or four-note melodic patterns that are defined by the intervallic contour. ${ }^{47}$ In this figure, + and - signs indicate the direction of pitch

47. Peter Burt also shows the recurring harmonic and melodic construction in Distance de Fée. In example 8 in his book The Music of Toru Takemitsu, Burt shows that the long melodic line is constructed out of recurrent smaller motives, which in turn provide 
motion by semitones. The same process of melodic writing can be seen in Requiem composed in 1957.

Figure 4. Distance de Fée, Violin Melody in mm. 2-6

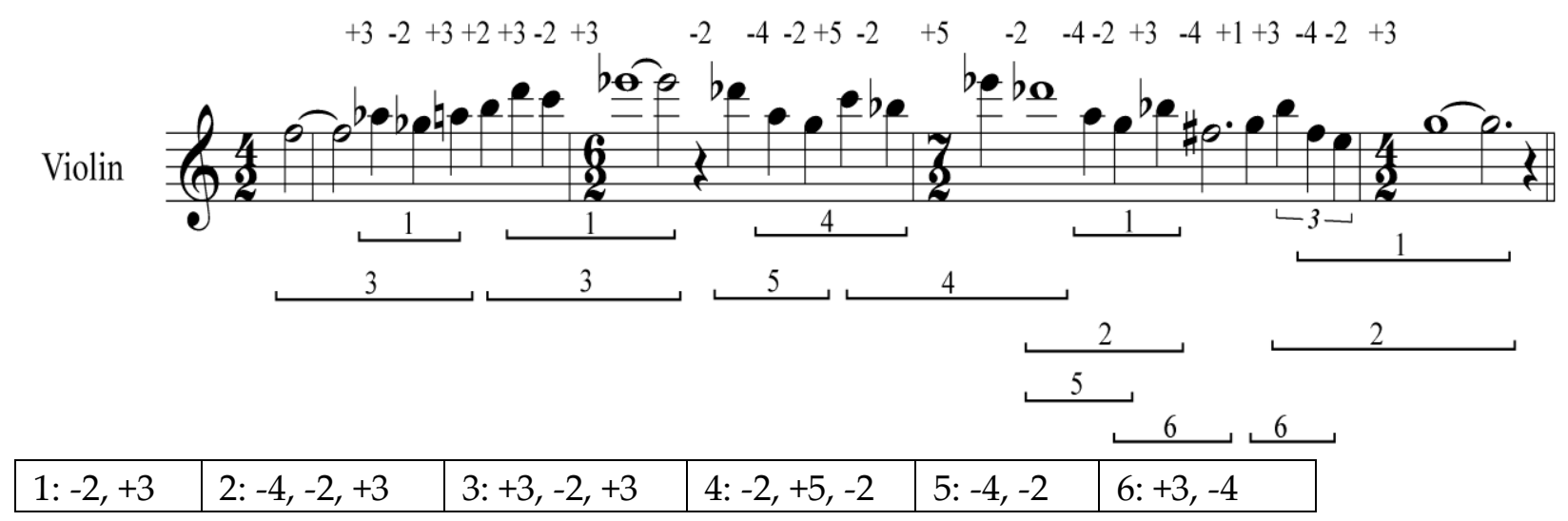

Source: Distance de Fée, 1951.

The year 1957 is another significant year for the Japanese concert music scene. The Karuizawa ${ }^{48}$ Contemporary Music Festival started in 1957, which was hosted by the above-mentioned Institution of $20^{\text {th }}$-Century Music, where Japanese composers, musicians, and audience were exposed to the works of European and American composers. Also a group called Hōgaku Yonin no Kai (literally translates as "a group of four people who play traditional Japanese music") was formed, which actively sought out and commissioned compositions that use traditional Japanese instruments. By the year 1957, aversion to traditional Japanese instrument was mostly faded and many composers started to incorporate traditional Japanese instruments in their music. Japan as a country has increased confidence after signing the Peace Treaty with the Allies, officially regaining the sovereign power with economic recovery.

The Requiem for Strings, commissioned by Tokyo Symphony Orchestra, was a composition that changed Takemitsu's life. The premiere, however, was not received well by the critics, until Stravinsky visiting Japan for the first time in 1959 having heard the Requiem, gave it highest praise that brought Takemitsu widespread recognition. The Japanese conductor Hiroyuki Iwaki writes that without Stravinsky's praise, Takemitsu's compositional path might have been quite different. ${ }^{49}$ Takemitsu was critically ill while composing the Requiem, and

new materials. See Burt, The Music of Toru Takemitsu, 35-38. My example shows the smaller motives overlapping each other or embedded in larger motives.

48. Karuizawa is located in the mountainous Nagano prefecture and is renowned as a summer resort for wealthy people who appreciated concert music and arts.

49. Hiroyuki Iwaki, Sakkyokuka Takemitsu Toru to Ningen Mayuzumi Toshiro (The composer Toru Takemitsu and the human being Toshiro Mayuzumi) (Okayama, Japan, 1999), 27. 
Hayasaka had just passed away. ${ }^{50}$ Both events deeply affected Takemitsu, prompting him to compose a work titled "Requiem."

Figure 5. Requiem for Strings, some Examples of the Three-note Figures in the Melodic Line

m. 1

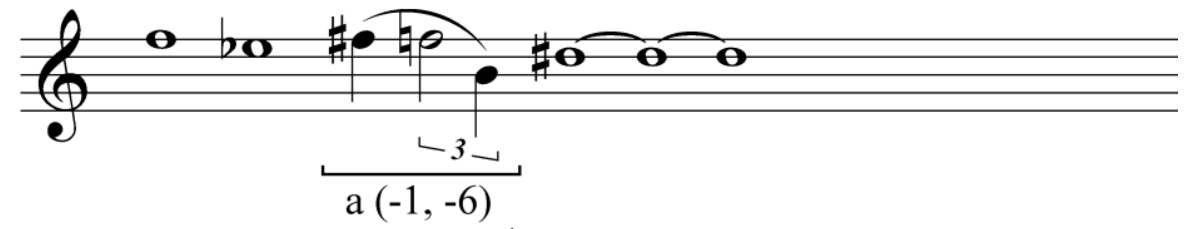

m. 6

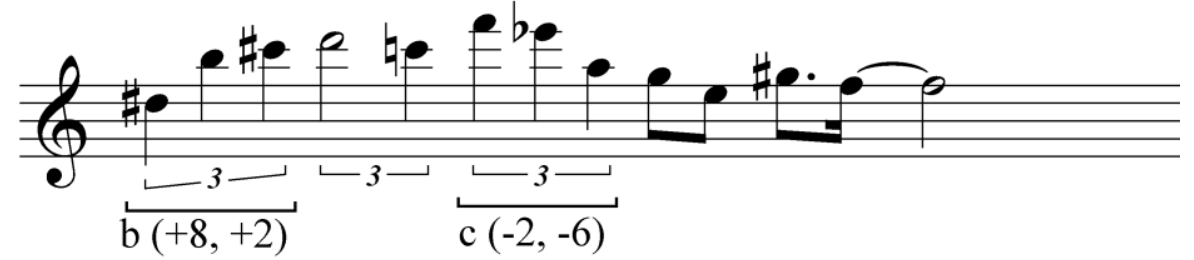

m. 10

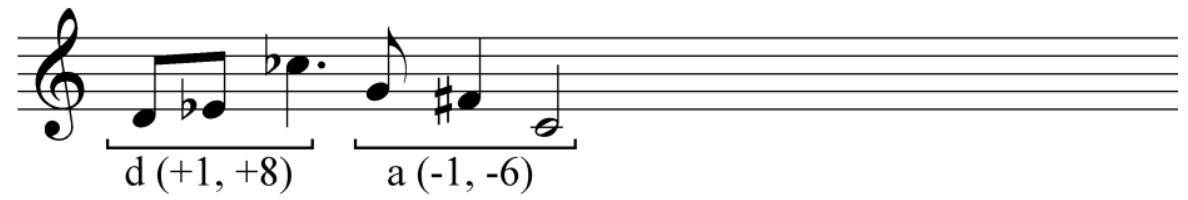

m. 13

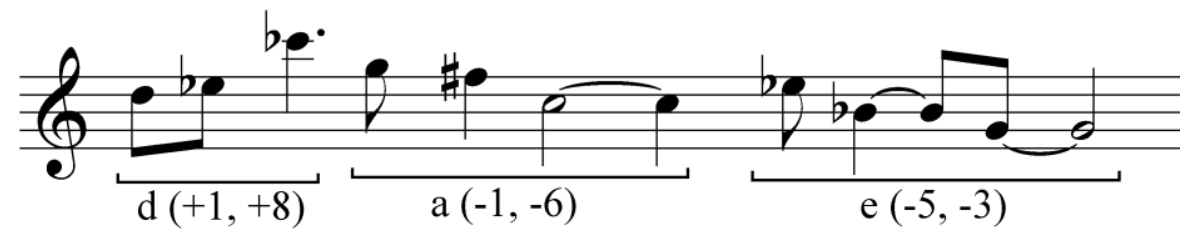

m. 15

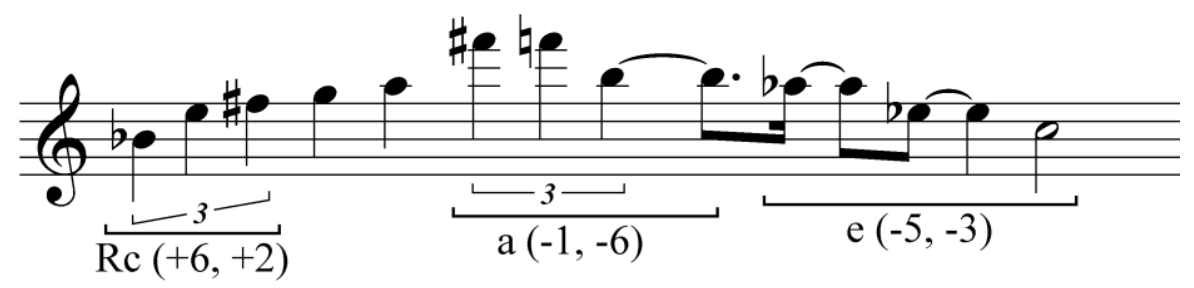

m. 18

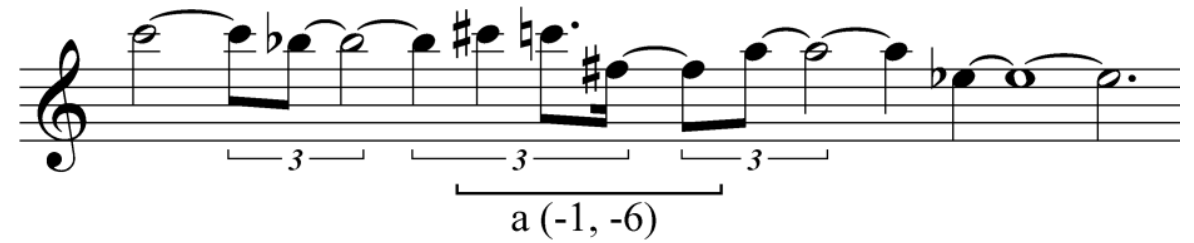

Source: Requiem for Strings, 1957.

When describing the Requiem, Takemitsu says the work has no clearly differentiated beginning or end, thereby lacking the kind of articulations

50. Takemitsu, Toi Yobigoeno Kanatani, 45. 
necessary for our usual definition of musical form. ${ }^{51}$ Using one of his favorite metaphors, he states that he simply "sliced off a piece of stream of sound" that flows eternally and pierces through the world that surrounds human beings. ${ }^{52}$ As the piece is dedicated to Hayasaka's death, this metaphor fits well with the eternal flowing image. Although octatonic and nonatonic chords are utilized throughout, ambiguities in the pitch derivations in the harmony, together with metric ambiguity, also contribute to this impression. However, it is the melodic writings in the Requiem, that mostly contribute to the impression of "the stream of sound." Numerous repetitions-both large scale and small scale-often overlap or are embedded with one another in the similar way they do in Distance de Fée, and it is this specific feature that creates a complexity in the perception of form.

In Distance de Fée, three or four notes patterns are embedded in the melodic contours. In Requiem, however, the listeners can identify one or more prominent and memorable three-note figures that serve to characterize the melodies. Figure 5 is an example of some three-note figures recurring throughout the piece. In this example, $\mathrm{R}$ before the letter name indicates that the three-note pattern is in the retrograde form of the original pattern. Many of the figures are triplets, and if not, in many instances two of the three notes are part of a triplet. These three-note figures recur throughout the piece but they do not develop, but rather contract or expand in time and reappear in a variety of combinations with other three-note figures. As a result, all melodic lines sound similar in character. These melodic lines continue one after another without clear sectional boundaries.

This characteristic of melodic lines has much in common with the melodic lines in Japanese traditional music. Hidekazu Yoshida describes the music of the Japanese traditional instrument shamisen (three-string instrument) as follows:

The music seems to be made up of the repetition of the same thing; however, it changes gradually, moving forward accordingly. Then in the next moment, suddenly it seems to return to an earlier moment. It is hard to tell if it has shape or not. Rather, it is music that from time to time expands or contracts and that keeps our attention by gradually transforming its form and color. The parts of music are interchangeable, and it is possible to start anywhere and end anywhere. It is essentially different from Western music, whose parts or sections have their definite formal position. ${ }^{53}$

51. In his book The Music of Toru Takemitsu, Peter Burt describes the overall structure of the Requiem, showing a diagram clearly in ternary form (p. 56). I have described elsewhere the roughly ternary form of the Requiem is not immediately evident because of the intricate repetitions and overlapping of the small melodic patterns.

52. Takemitsu, Toi Yobigoeno Kanatani, 46.

53. Mitsuo Aki, "Takemitsu Tōru to Nihontekinamononitsuite" (About Tōru Takemitsu and the Japaneseness), in Takemitsu Toru no Sekai (The world of Toru Takemitsu), ed. Shinji Saito, and Maki Takemitsu (Tokyo: Shūeisha, 1997), 129. My translation. I have used the same quote to describe the characteristics of the traditional Japanese flute elsewhere. 
In traditional Japanese music, each section seems to be a ceaseless repetition of a similar pattern; however, as time passes, the pattern sometimes expands or contracts according to how the energy flows. Different from a Western style that has a definite beginning and melodic goals, thematic and motivic development, a Japanese style cultivates a perpetual transition of parallel events without a defined framework. It is sometimes metaphorically characterized as a flowing of water, and this is what Hayasaka calls an "eternal form."54

Finally, the works I have discussed here do not have a clear sense of pulse or even a sense of periodicity. ${ }^{55}$ Many writers discussed the concept of ma evident in Takemitsu's music as meaningful silence between musical events, another aspect that alludes to ever flowing water or the rhythm of nature.

\section{Conclusion}

Although the works I discuss here were composed before Takemitsu produced the so-called "avant-garde" pieces (such as musique concrete works, music with graphic notation, and chance music, which blossomed in the 1960s and the 70s), Takemitsu undoubtedly inherited the experimental spirit from Takiguchi more than anything else. Tezuka writes that Takiguchi entrusted with the members of the Experimental Workshop with the task of reviving and continuing the avant-garde movement that once flourished around him but was halted during the war. ${ }^{56}$ Takemitsu was quick to test the compositional styles that he learned from Western composers. This is also true with his earlier pieces, in which he experimented with the octatonic collections and other modes of limited transposition that he learned through Messiaen's compositions. Even with the utilization of the octatonic collections, we can observe Takemitsu's stylistic development in a short amount of time between Distance de Fée and Pause Ininterrompue. Takemitsu's interest in the dodecaphonic method is observed in the beginning of the first movement of Pause Ininterrompue, and later, the serial procedure is attempted in the second and third movements of Pause Ininterrompue, and in some parts of Piano Distance.

Influences from Hayasaka in Takemitsu's music instantiate as ambiguities in harmonic procedures, and the melodic writing demonstrates the "stream of sound" in which Takemitsu claims that the piece has no clearly differentiated beginning or end. The musical events are in some way variations or varied repetitions of each other that occur continuously without any hierarchical positioning between these events. The music is heard from one sonority to

54. Ibid., 84 .

55. I have discussed the obscurities of the rhythmic and metric perception of the Requiem elsewhere.

56. Tezuka, Jikken Kōbō, 29. 
another in time, obscuring the boundaries of the beginnings and endings without a clear goal or climax. Hayasaka's idea translates in music as non-functional and non-developmental harmonic and melodic lines whose continuation emulates the Japanese picture scroll. This might be what Hayasaka means by two-dimensional and what Takemitsu called the "stream of sound" that he pursued. Starting in the 1960s, Takemitsu sought new possibilities in incorporating traditional Japanese instruments in his music, most famously integrating the Japanese traditional instruments shakuhachi and biwa in November Steps (1967) that was commissioned by the New York Philharmonic Orchestra. ${ }^{57}$ Although Takemitsu less frequently incorporated Japanese instruments in his music during the last two decades of his career, he was always conscious of projecting Japanese sensibilities in the formal procedure and temporality in his music.

Takemitsu's pieces with the titles from Takiguchi's poems might strive for the surrealist's principles in this way: to deny transparent communication, and to advocate for coexistence of conflicting realities. These qualities manifest themselves in the music as ambiguous perception of periodicity, and also as ambiguous referential pitch resources. Harmonic and melodic constructions are obscured by means of invariances and by superimposition of two different octatonic collections as pitch derivations. The purposeful overlapping and obscurities of pitch derivation in the Requiem might embody the surrealist's principle of coexistence of multiple realities.

For Takiguchi, the final line in Pause Ininterrompue, "Motionless spherical mirror on top of the hill," depicts the isolation he has been feeling as the society became more oppressive. Takemitsu described his Western and Eastern compositional inspiration as gazing into the Western and Eastern mirror. For Takemitsu, "the spherical mirror" might symbolize his mirror that has no direction of reflections as Western or Japanese, but reflects any world that could be seen from the top of the hill, which results in his music the coexistence of the two different worlds; Western but also retaining an unmistakable Japanese quality.

\section{Bibliography}

Aki, Mitsuo. "Takemitsu Tōru to Nihontekinamononitsuite" (About Tōru Takemitsu and the Japaneseness). In Takemitsu Toru no Sekai (The world of Toru Takemitsu), edited by Shinji Saito, and Maki Takemitsu. Tokyo: Shūeisha, 1997.

Akiyama, Kuniharu. Nihon no Sakkyokukatachi: Sengokara Shin no Sengotekina Mirai e (Japanese composers: from post-war to truly post-war like future). Tokyo, 1979.

57. This double concerto brought Takemitsu international recognition. 
Burt, Peter. The Music of Toru Takemitsu. Cambridge: Cambridge University Press, 2001.

Herd, Judith Ann. "The Neonationalist Movement: Origins of Japanese Contemporary Music." Perspectives of New Music 27, no. 2 (1989): 118-163.

Iwaki, Hiroyuki. Sakkyokuka Takemitsu Toru to Ningen Mayuzumi Toshiro (The composer Toru Takemitsu and the human being Toshiro Mayuzumi). Okayama, Japan, 1999.

Katayama, Morihide. "Senzen, Senchuu, Sengo" (Pre-war, inter-war, post-war). In Nihon Sengo Ongakushi, Jōkan (Japanese history of concert music after World War II, Book 1), edited by Kōji Sano. Tokyo: Heibonsha Ltd., 2007.

Kobayashi, Jun. Nihoneigaongaku no Kyoseitachi I (Bright stars in the Japanese film music I). Tokyo: Waizu Shuppan, 2001.

Koozin, Timothy. "Toru Takemitsu and the Unity of Opposites." College Music Symposium 30, no. 1 (1990): 34-44

Miura, Atsushi, and Hayasaka, Fumio. "Hayasaka Fumio to Han-Tōyōshugi Ongakuron" (Fumio Hayasaka and musical discussion on pan-Asianism). Ongakugeijutsu (August, 1954): 8-20.

Nihon no Sakkyoku 20 Seiki (Japanese composers and compositions in the 20th century). Tokyo: Ongakunotomosha, 1999.

Nishimura, Yūichirō. "Kurosawa Akira to Hayasaka Fumio: Kaze no youni Samurai wa" (Akira Kurosawa and Fumio Hayasaka: Samurai like the wind). Tokyo: Chikumashobō, 2005.

Ōoka, Shin. Mikurokosumoso Takiguchi Shūzō (Microcosmos, Shūzō Takiguchi). Tokyo: Misuzushobō, 1984.

Sano, Kōji. Nihon Sengo Ongakushi, Jōkan (Japanese history of concert music after World War II, Book 1), edited by Kōji Sano. Tokyo: Heibonsha Ltd., 2007. Introduction. Nihon Sengo Ongakushi, Jökan (Japanese history of concert music after World War II, Book 1), edited by Kōji Sano. Tokyo: Heibonsha Ltd., 2007.

Sano, Hitomi. "Takemitsu Tōru to Senzen no 'Minzokuha' Sakkyokukatachi: Kiyose Yasuji, Hayasaka Fumio to 'Nihon tekina mono' no Ninshikinitsuite" (Toru Takemitsu and 'Ethnic' Composers of the Prewar Period in Japan: Yasuji Kiyose, Fumio Hayasaka, and their Recognition of 'Japanese' Music). Hyougenbunkakenkyū 10, no. 2 (March 2011): 171-183.

Tachibana, Takashi. "Takemitsu Tōru: Ongaku Souzoueno Tabidaisankai" (Tōru Takemitsu: Journey to music creation no. 3). Bungakukai (1992).

Takaku, Satoru. "Sengosedai no Taitou" (The rise of the post-war generation). In Nihon Sengo Ongakushi, Jōkan (Japanese history of concert music after World War II, Book 1), edited by Kōji Sano. Tokyo: Heibonsha Ltd., 2007.

Takemitsu, Toru. Confronting Silence: Selected Writings. Translated and edited by Yoshiko Kakudo, and Glenn Glasow. Berkeley, California: Fallen Leaf Press, 1995.

Toi Yobigoe no Kanatani (Beyond the far calls). Tokyo: Shinchosha Publishing, 1992. 
_. Takemitsu Tōru Taidanshuugekan: Sōzō no Shūhen (Tōru Takemitsu's collection of dialogue vol. 2: Around creation). Tokyo: Geijutsugendaisha, 1976.

_. "Contemporary Music in Japan." Perspectives of New Music 27, no. 2 (1989): 198-204.

Tezuka, Miwako. Jikken Kōbō (Experimental Workshop): Avant-Garde Experiments in Japanese Art of the 1950s. PhD dissertation, Columbia University, 2005.

Tōyama, Kazuyuki. Collection, Book 1. Tokyo: Shinchosha Publishing, 1986.

Tsuruoka, Yoshihisa. "Kyouhakusareta Zettaizetsumei: 'Yousei no Kyori' kara 'Te' e" (The threatened serious crisis: from Distance of Fairy to Hand). Hon no Techou (August 1969): 428-438. 
